\title{
Living at the Margins: Black Feminist Pedagogy as Transformative Praxis During the 1980s-1990s and Epistemic Exclusion in the 21st Century—Where Do We Go Now?
}

\author{
Dolana Mogadime \\ Brock University \\ dmogadime@brocku.ca
}

\begin{abstract}
In this essay I argue that Black women who teach Black feminist pedagogy experience "epistemic exclusion" (Buchanan, 2020) while advocating for the intersections between three disparate contexts: their activism in their communities, the women's movement, and their work as educators in postsecondary settings. The period examined is the 1980s-1990s. I consider the institutional challenges and limitations Black women have undergone as knowledge producers and teachers. While pushing the boundaries erected between university settings and the Black liberation movement taking place in their communities (Joseph, 2003), they were limited to a precarious status as Black women teaching within White-male dominated institutions. The trailblazing theoretical pedagogical insights Black feminists have advanced in their work as educators in postsecondary settings is discussed at length. Additionally, connections are made to the present-day struggle among Black feminists for inclusion within contemporary educational contexts (Evans-Winters \& Piest, 2014; Mogadime, 2002, 2003; Wane, 2009, 2011).
\end{abstract}

\section{Introduction}

Although the theoretical insights and inroads Black women made through their pedagogical practices - referred to as Black feminist pedagogy_during the 1980s and 1990s has been discussed at length, this paper argues that the knowledge basis for such discussion was often discounted and marginalized in the academy and continues today through what researchers refer to as epistemic exclusion. Buchanan (2020) defines epistemic exclusion as:

a professionalized version of social exclusion and disregard, in which bodies of knowledge, knowledge production, and the producers of knowledge are excluded from traditional discourse within a scholarly discipline (Dotson, 2012, 2014). Epistemic exclusion operates formally and informally (Dotson, 2014; Settles, Buchanan, \& Dotson, 2019; Settles, Jones, Brassel, \& Buchanan, 2019; Settles, Jones, Buchanan, \& Dotson, 2019). (Buchanan, 2020, p. 93)

With the resurgence of interest in the Black liberation struggle (Joseph, 2003), manifested through the Black Lives Matter movement, it is increasingly important to examine the historical roots and theoretical contributions of Black feminists to the social sciences and humanities, as 
well as the agency they exerted while undergoing epistemic exclusion in the academy. Given the continued underrepresentation of Black women in academe today, these experiences should be revisited as a framework to: examine the strategies Black women used for their survival as academics; question who can and should speak on behalf of the Black Liberation movement in postsecondary classrooms today; and hold institutions accountable for supporting the hiring of Black women into academic positions.

\section{Black Feminist Pedagogy: Historical Roots}

It is appropriate to begin this paper by defining and discussing what is meant by the term Black feminist pedagogy. Then I will carry the discussion further by describing its transformative praxis within the classroom and university curriculum. I will conclude with a brief critical analysis of the limitations of Black feminist pedagogy that has arisen from this specific historical area of intellectualizing. The present paper relies almost entirely on the writings of Black feminists in United States of America (USA), save the writings of African Canadians Linda Carty (1987, 1991, 1993), Annette Henry (1992), and Peggy Bristow (1994). The concerns of Canadian Black feminist educators are captured by Bristow (1994), who explains that,

we are part of the larger community of Black women in the Americas, all of whom share inferior status based on race. This holds true for all women of African descent in the Americas: Canada, the Caribbean, and Latin America. It is crucial to an understanding of Black women's history in Canada to locate our experiences within this broad framework. (p. 70)

It is my belief that our location within what Bristow identifies as a 'broad framework' empowers us to speak and break the silence of oppression. Additionally, as Carty (1991) asserted regarding her own presence, teaching to "all white classes" in a university setting, Black women teachers in the academy are "extremely rare" (p. 40). For that reason, the historical analysis of Black feminist pedagogy draws heavily from the USA. I demonstrate how this historical understanding has implications for the Black feminism within the Canadian contexts (Mogadime, 2002, 2003; Samuel \& Wane, 2005; Wane, 2009, 2011) in contemporary times, a discussion that I raise in the latter sections of this paper.

Black feminist pedagogy has evolved and grown out of "Black women's historical experience with race/gender/class/bias" (Omolade, 1987, p. 32). It seeks to expose and transform the very roots of Black female subjugation and suppression: the knowledge paradigms that are based on the interests and goals of the dominant group, being the Western-centric and male-centric canon that dominates the university curriculum and the existing social order it creates. A Black feminist pedagogy informs and confronts students with the reality that knowledge is socially constructed and is used to support power-group relationships in society. The false presupposition of an objective, neutral knowledge basis for academic scholarship is scrutinized and problematized when it is made clear that this knowledge functions to legitimize the dominant political, economic, and cultural arrangements within a society that systematically marginalizes the experiences of people of color and women (Carty, 1987, p. 12). The image Linda Carty invokes in her definition of the term "women of Color" is very helpful. Clarification of the meaning of the term is crucial, because it has been misinterpreted and used in a way to signify "racial 
identity in opposition to white" (p.12). However, Carty's definition sets the record straight by stating the following:

Recently, however, many women of Color feminists have been "charting the journey" (Mohanty, 1991) of women of Color living both in the West and in the "Third World." They write of "women of Color" or "Third World women," not as women who constitute an automatic unitary category based on geographic location or racial identity in opposition to white but as women sharing a common post-colonial struggle based on their differential though intersecting histories of slavery, colonialism, imperialism, racism and genocide in capitalism. Their scholarship locates women of Color not in terms of their problems and oppression in binary oppositional categories to white Western women, but as women with conscious agency in a daily struggle against their oppressors. (Carty, 1987, p. 12)

A Black feminist pedagogy seeks to facilitate students in the process of deconstructing the existing social order. It engages students in challenging the dominant paradigms, knowledge systems, and perspectives that are institutionalized within society (Giroux, 1991). Omolade (1987) identitifies what is at the heart of Black feminist pedagogy when she assertes, that it "aims to develop a mindset of intellectual inclusion and expansion that stands in contradiction to the Western intellectual tradition of exclusivity and chauvinism" (Omolade, 1987, p. 32).

Additionally, she suggests,

"it offers the student, instructor, and institution a methodology for promoting equality and multiple visions and perspectives that parallel Black women's attempts to be and become recognized as human beings and citizens rather than as objects and victims" (Omolade, 1987, p. 32).

Black feminist pedagogy simultaneously seeks transformative ends in the minds of the students in classrooms and in the curriculum of the universities. Within the challenges it poses to teaching practices and curriculum content, it manifests and thrives on the feminists' agenda - that is, praxis (theory and action) — in the life and work of teachers and students alike.

\section{The Political Agenda of Black Feminist Thought}

Investigating the pedagogy and political standpoints from which Black feminist theorists teach in academia is a twofold process. First, as mentioned previously, the pedagogy seeks to inform, transform, and liberate the thought process of students who have been marginalized (based on class, race, gender, and/or sexual orientation) by Western paradigms that represent the university and society at large. Second, Black feminist pedagogy seeks to transform the university as a site that suppresses the knowledge production of individuals who do not count themselves amongst members of the dominant, White patriarchal power structure.

The practice of utilizing pedagogy for liberatory ends is rooted in the theory of critical pedagogy advanced by Paulo Freire and "further critiqued and developed by the practice and theoretical understandings of people of color and of women" (Das Gupta, 1994, p. 40). In this way, Black feminist pedagogy shares the political standpoint of White feminist critical pedagogy; however, 
there is something distinct - a knowledge basis from which Black feminists work that makes their approach different from that of white feminists. I ascribe such difference to Black feminists' cultural identity as people of African descent and their resulting location in the oppressive systems of racism, classism, and sexism that define the existing social order in our society. I agree with the Afrocentric perspective that posits,

all experience is culturally grounded, but that one is most centered psychologically when experiences are viewed from one's cultural and psychological center. This is particularly true when you speak of African culture and experience. Not to be centered means that you exist in the margins. (Asante, 1993, p. 8)

I will reveal the ways in which critical pedagogy espoused by Black feminists is unique, because it is rooted in historical Afrocentric traditional philosophical epistemology. These traditions need to be named and acknowledged for the purpose of highlighting the particular insights Black feminists bring to pedagogy in academia. As I read through the writings of Black feminist educators in academia, I began to sense the sociological paradigms from which they operate. The pedagogy Black feminist educators advance carries an Afrocentric perspective in that it supports an ideology that acknowledges African continuities in African American communities.

The theoretical underpinnings are located in a specific place that dramatically contradicts Western forms of abstract logic. Black feminist theorizing is rooted in praxis that intends to name and transform the oppressive systems that constrain African people, both as individuals and as communities. As Joy James (1993) in "Teaching Theory, Talking Community" explains, "within an African and community-centered tradition, the creativity of a people in the race for theory sustains humanity" (p. 118).

\section{Afrocentric Philosophical Epistemology}

African traditional (philosophical) thought and theorizing is a praxis dedicated to communal and unifying ends. The African ways of thinking and being that are based on the West African proverb "I am because we are-we are because I am" signals the sacred links between the personal and communal. Knowledge in the African theoretical tradition is personally related to who people are both as individuals and groups. As such, it challenges the individualistic basis of Western thought which is premised on the "I think, therefore I am" Cartesian perspective with the West African proverb "I am we" (Butler, 1991b, p. 75).

The historical roots of Black feminist theorizing needs to be articulated to understand its connection, commitment, and dedication to an emancipatory manifesto for the Black community today. In this way, it is in fact personal knowledge- for all Black women and men alike. In this sense the theory has at its center the African concern for the survival and improvement of the community. Placing the theory of Black feminist thought within this Afrocentric identity or knowledge basis clarifies the praxis upon which it operates within "a dialectic of oppression and activism" (Collins, 1991, p. 5). The theory has grown out of the tradition to further the race. The historical writings and activism of Black women was voiced for the purpose of what came to be known as "racial upliftment" (p.147). Throughout history, Black women's activism has demonstrated a commitment to the survival and continuity of the African culture. This 
ideological framework is evident in their community activism.

Bagele Chilisaa and Gabo Ntseaneb (2010) "employ postcolonial and indigenous standpoints to reveal local standpoints that express girls/women agency and resistance to patriarchal oppression" (pp. 617-618). To the authors, the identity of motherhood is central. They explain,

the variety of African feminisms in contrast to other feminisms emphasize the centrality of motherhood in African households and family organization and the agency and power of mothers as the source of solidarity. Unfortunately, the othering of motherhood and the denial of the importance of African relational gender roles, it is argued, relegates the African women to subject/victim and further conceals how girls/women have used the relational gender roles as sites for resistance and sources of empowerment. (p. 618)

Black feminism allows me to be connected to other Black women's struggles in North America. It assists in identifying the common threads that bind us together and from which we can speak with unified power to resist the remnants of colonialism, namely white supremacy and cultural hegemony. I also embrace the work of Black writers located in the western hemisphere who identify and respect African history and sensibilities. For these two reasons, I embrace the work of Black feminists and Afrocentric feminists' scholars. In this work I draw from their contributions to advance their communities in and through their academic work. I believe it is important to know this work. Their teaching approaches embrace connections to the Black community, and they see their role as contributing to and advancing the life changes of Black women, youth and their families in and through education.

\section{The Praxis (Theory and Action) Within the Lives of Revolutionary African Women}

Black women throughout history represent a force that is "not content" to simply point out "the source of oppression" as racism and sexism (Collins, 1991, p. 3). Maria Stewart, a hallmark representative figure of Black feminist thought, lectured in 1833 in order to question and attempt to transform the inferior position and perception of Black womanhood that was characteristic of the time period (Collins, 1991, p. 3). Black feminists carry on the same themes raised by Stewart. Patricia Collins's analysis of Stewart's speeches is especially significant because it zeros in on the image of Black women as politicizing their thoughts and experiences. Through the writings of the political thinker Mary Stewart, we see a perspective of Black women as intellectualizing and analyzing how oppression impacts on them. Even more importantly, Stewart's writing is significant because we see how Black feminist thought is linked to politicizing for the purpose of changing the forces of oppression. Collins (1991) acknowledges Stewart as "one of the first feminists to champion the utility of Black women's relationship with one another in providing a community for Black women's activism and self-determination" (p. 4).

\section{African Canadian Peggy Bristow's (1994) study of Black Women in Buxton and Chatham} 1850-65 identifies how Black women as individuals and collectives forged for self-improvement and racial advancement in a spirit of self-definition that refused to be enslaved and constrained by the ideologies of racism and sexism. Black women's resistance has operated with the goal of transformation not only for the individual but also for the communal members who share a common descent from Africa. The narratives I studied in several anthologies' articles reflected 
Black women as knowledge producers who exerted activism in their classroom. Davis (1993) describes their contributions steeped in the "experiences, theorizing, and practices" (p. xi). These narratives testified that Black feminist scholars were actively engaged in the struggle for group survival and institutional transformation (Collins, 1991, p. 142).

\section{Black Feminists Who Teach Black Students Bring the Vision of the Struggle for Group Survival Into the Classroom}

Black feminist scholars who have become educators in academia enter the classroom with "cultural perspectives, values, hopes and dreams" (Banks, 1991, p. 139) that are informed by their link into the community. Black feminist presence, or more precisely her "theoretical insights and educational practices ... cross the diverse divides separating disciplines, cultures, spiritual practices and theoretical paradigms, as well as those that separate the 'academy' from the "community"' (Davis, 1993, p. xi). The common link between these educators is that they work steadily at the task of creating links between their community and the university.

This entails taking traditional African roles within their capacities as teachers. For instance, Patricia Coleman-Burns (1993) perceives her role within that of an educator as including also another special role: that of an "elder." African Canadian educator Annette Henry (1992) refers to this dialogue of caring and nurturing in the classroom as "othermothering" (a concept that represents African continuities in the African Diaspora). As an elder, Coleman-Burns provides a space in her classroom to advise and guide Black students. This relationship is particularly important when we consider the implication of nihilism in America among Black youths.

According to Black popular cultural analyst Cornel West (1994),

in fact, the major enemy of Black survival in America has been, and is neither oppression nor exploitation but rather the nihilistic threat, that is, loss of hope and absence of meaning. For as long as hope remains and meaning is preserved, the possibility of overcoming oppression stays alive. The self-fulfilling prophecy of the nihilistic threat is that without hope there can be no struggle. The genius of our Black foremothers and forefathers was to create powerful buffers to ward off the nihilistic threat, to equip Black folk with cultural armor to beat back the demons of hopelessness, meaninglessness, and lovelessness. These buffers consisted of cultural structures of meaning and feeling that created and sustained communities; this armor constituted ways of life and struggle that embodied values of service and sacrifice, love and care, discipline and excellence.... These traditions consist primarily of Black religious and civic institutions that sustained familial and communal networks of support ... until the early seventies Black Americans had the lowest suicide rate in the United States. But, now young Black people lead the nation in suicides.

(West, 1994, pp. 23-24)

In the absence of the influence of the church and the family as social communal institutions to combat nihilism, schools and universities remain the only institutions in which youths are compelled to participate. Therefore, Black educators play an even more crucial role as teachers in guiding, nurturing, and preserving the next generation of Black people, who have the potential Journal of Contemporary Issues in Education, 2021, 16(2), pp. 3-20. (c) Author(s), Creative Commons Attribution 4.0 (CC BY 4.0) licence http://ejournals.library.ualberta.ca/index.php/JCIE 
to become community leaders, intellectuals, and scholars. There is growing concern among Black intellectuals that "the current Black intellectual presence in academia, small as it is, will not be reproduced (Carby, 1992, p. 189). Hazel Carby (1992), bell hooks (1981, 1984, 1989, 1991), and many other Black intellectuals (too many to cite here) reaffirm the need for the university to become a location where people of disadvantaged groups can be given the opportunity to readdress social inequalities.

I am using Coleman-Burns's (1993) findings from her course entitled "Black Social and Political Thought: Theory and Practice" to illustrate how Black educators are informed by insights into the Black community and, more importantly, how they utilize these insights to equip students with analytic tools to become critical of the systems of oppression, and sharpen their ability to become agents of change that confront and transform these imposing limitations. These are skills that are necessary for their communal survival. The following description gives a brief outline of the intention of Coleman-Burns's course to confront the "enemy without":

[It] is designed to examine several key African American ideological perspectives that interpret events, and project change and transformation of the collective peoples and of society. This examination often involves application of theory to current issues and events within the African American community and larger society. In early lectures we discuss the institutionalized and systemic nature of racism and its manifestations in the academy, the media, and society. We talk about racism in textbooks of higher education which distort and diminish the importance of the Ancient Egyptians (Kemetians) as part of the continent of Africa. We also analyze the negative press coverage on African Americans which can be seen daily in local papers. (Coleman-Burns, 1993, p. 149-150)

Further important aspects of Coleman-Burns's course is the critical analysis of what she refers to as "the dialect of the enemy" both "outside" and "inside" as central for "revolutionary transformation" (p. 152). According to Coleman-Burns (1993), the concept of "the enemy within" entails confronting "one of the fundamental issues that we, the African American community, have consistently been reluctant to confront, that is, our own complicity and role in our continuing oppression" (pp. 152-153). Actions from the "enemy within the community" were characterized as "counterrevolutionary" tendencies that students needed to recognize as such in order to combat against them (p. 153). Coleman-Burns involves her students in analyzing the dialect of the enemy within and without in order to engage them in becoming active participants in understanding and helping to change the world.

\section{Black Women Teachers Profess a Transformative View of the University Curriculum}

Comparative Women's Studies scholar Johnnella E. Butler (1991a), argues that transformation of disciplinary boundaries in the social sciences can be forged by integrating the scholarship of Black women and women of colour into the curriculum. She asserts that the study of Black women and women of colour should be infused into a range of disciplines. In her capacity as a university professor, Butler supports a methodology and pedagogy that draws from the critical pedagogy, feminist pedagogy and antiracist pedagogy that is implicit in women's studies and ethnic studies (as it embodies all ethnic groups). She advances the notion that teaching about women of color is at the core of transforming the liberal arts curriculum. Butler teaches about 
women of color as a pedagogic tool for the reason that certain learning processes are inherent in this study. Butler (1991b) describes "what we learn from studying women of color" as a "raising [of] our awareness and understanding of the experiences of all women either implicitly or directly" (p. 69).

Butler details her pioneering commitment towards partnering the scholarship of women's studies and Black studies. She successfully outlines the limitations of both fields (using Audre Lorde's concept of the master's tools still at work) in their autonomous attempts to challenge political and cultural hegemony. The scholarship of Women's Studies has "characteristically focused on white patriarchy" (1991a, p. xx), for the reason that it has "used the master's tools" to achieve this end. Given the underpinnings, she provides a convincing critique as to why women's studies, save some exceptions, unfortunately, "reflects the racial and cultural biases of Western scholarship" (p. xx). With the same sharp critique, she turns to Black studies and ethnic studies to point out their limitations in "the use the master's tools" by "reflecting the patriarchal biases of Western scholarship" (p. xx) in their emphasis on dismantling racism and colonialism. Transforming these theoretical flaws, according to Butler, involves working on the full incorporation of women and men of color and White women into the liberal arts curriculum within the academy. She supports the view that "the experience of the woman of color is the bridge that joins us all. She is the link between Ethnic Studies and Women's Studies content, and as such occupies a pivotal place in curricular change" (pp. xix-xx). The question that may come to mind is how?

\section{Interlocking Systems as a Corrective}

Within the insider-outsider stance espoused by Patricia Collins (1986), Black feminist thinkers have increased the scholarly level of awareness and understanding of how the mechanisms of oppression operate in a multi-dimensional praxis. Black feminists herald their task as "the development of integrated analysis and practice based upon the fact that the major systems of oppression are interlocking" (Combahee River Collective, 1982, p. 13). In their mission statement ("A Black Feminist Statement"), the Combahee River Collective defined their politics and political work in this vein: "as Black women, we see Black feminism as the logical and political movement to combat the manifold and simultaneous oppression that all women of color face" (p. 13). Barbara Smith (1983) voiced their groundbreaking work when she stated; "The concept of the simultaneity of oppression is still the crux of a Black feminist understanding of political reality and, I believe, one of the most significant ideological contributions of Black feminist thought" (p. xxxii).

The result of Black feminist intellectualizing "is the attempt to uncover how complex modes of inequality are structured through racial, class, and gender divisions" (Giroux, 1991, p. 236) These insights represent the shift in "analyzing the dynamics of domination from the margin to the center of power. These divisions lie at the heart of the dominant culture and by definition serve to shape its most basic institutional and ideological forms" (p. 236). The implications of these insights are that scholars who are representative of the dominant culture are now compelled to acknowledge the need to establish that, 
racial identities are also white that must be seen as specific historical and social constructions. ... This is imperative in order to understand how whiteness serves as a norm to privilege its own definitions of power while also concealing the political and social distinctions embedded in its essentialist constructions of difference through the categories of race, gender, and class. (Giroux, 1991, p. 236)

The study of women of color is instrumental in transforming an analysis from the essentialism notion that has characterized "dominant humanist theory" to viewing identity as something that is fluid, shifting, and multiple rather than something that is fixed (Giroux, 1992, p. 127). Recognizing the fluidity of identity allows for the emergence of voice from different locations. It involves "disorganizing ideology and disorienting individuals" (Culley, 1985, In Butler, 1991b; p. 79). This is inherent in bringing the voices to the center that have been subjugated and silenced within the essentialist construct of difference as it is articulated through the categories of race, gender, and class. Teaching about women of color for the purpose of deconstructing and transforming perspectives that have at their center the ideology of racialized and gendered dominance entails "alter[ing] all students' perceptions of themselves" (Butler, 1991b, p. 79).

Butler (1991b) outlines how a specific methodology for gathering and interpreting content is instrumental in reaching transformative ends (pp. 73-78). Butler facilitates students' engagement with decentering the normalized reference point; for example, they begin to question the concept of "women" as meaning only White women and replace this preconceived viewpoint with one that values differences among women. In this way students are challenged to think outside the notions of White middle class as the norm. While classroom discussion of this nature may lead to student reactions involving both surprise and anger (p. 79), Butler (1991b) argues that these responses and dialogue can lead to transformation in thinking. Teaching then contributes toward altering grounds of being that are inherent in teaching from multifocal, multidimensional, egalitarian, and interdisciplinary perspectives as espoused by feminist and antiracist pedagogy (p. 73). This process entails challenging and ultimately displacing the ways in which the Western mind orders the world. The goal of these pedagogues is to:

transform the curriculum with content about women and ethnicity to provide an education that more accurately reflects the history and composition of the world, that demonstrates the relationship of what we learn to how we live, that implicitly and explicitly reveals the relationship between knowledge and social action. (Butler, 1991b, pp. 78-79)

Butler achieves these pedagogic ends by introducing the "biographies, poetry, and storytelling"of women who represent "different experiences" according to race, class, ethnicity, and gender roles (p. 78). These materials provide a forum to illustrate what it means for people of color and oppressed individuals to have a voice. The narratives reveal how the personal is linked to the political. They link theory with action in women's attempts to resist objectification and assert subjectivity as a means to validate their social reality. This links to the recognition that women's "subjectivity is denied in male hegemonic ideology and language" (Weiler, 1988, p. 62). The emphasis on the connectedness of experiences among women of color and White feminists and the points of commonness in the pedagogy they espouse is evident in their similar emphasis on teaching as "counter-hegemonic work" (p. 67). 
Within the emergence of multiple voices is the recognition of the need to "engage voice as an act of resistance and self-transformation" (Giroux, 1992, p.130). Further, students recognize that as those who were silenced and subjugated come to voice, they establish the precondition for becoming a subject in history rather than an object. With the rejection of objectification of subjective experiences comes recognition of the deeply political nature of everyday life.

Exploring counter-hegemonic and liberatory teaching and learning "forces people to interrogate their own common-sense view of the world and to move toward critical consciousness of their relationships and position in society" (Weiler, 1988, p. 71). Afrocentric feminist, antiracist, and critical feminist pedagogy is committed to a praxis that is founded on not understanding the world but changing it. These movements are connected in their recognition that intrinsic to the movement towards changing oppressive relationships and forms of power is the commitment to social change and agency. They share in common the political commitment to changing the existing social order by rejecting individualism and taking collective action (Briskin, 1990, p. 26).

\section{Black Feminists Challenge Exclusions in Women's Studies}

As women whose backgrounds do not represent the middle class and privileged location that has taken for granted the 'bourgeois class biases of feminist activists', Black feminists continually critique the discourse of women's studies that excludes women from subordinate classes. As women who come from similar socioeconomic backgrounds as their students, Black feminists have a unique insider-outsider vantage point that informs them of the needs of Black students. They use their role as teachers to develop a methodology for effectively teaching writing and literacy skills to those groups of students who have historically been excluded from education of this sort. Michele Russell (1982) in "Black-Eyed Blues Connections: Teaching Black Women," bell hooks (1984) in Feminist Theory: From Margin to Center, and Barbara Omolade (1987) in "A Black Feminist Pedagogy" focus on teaching women to read, write, and think effectively as essential aspects of feminist education.

hooks $(1989,1994)$ implored autobiographical narrative to elucidate her experiences growing up in a working-class community in the Southern states and how her teachers, who were overwhelmingly Black females, transferred an understanding about "education as a practice of freedom" (hooks, 1994, p. 4) to her. hooks went through great lengths to explain the significant role these teachers played in contributing toward the education of Black children:"For black folks teaching - educating - was fundamentally political because it was rooted in antiracist struggle.” (p. 2). hooks' teachers envisioned themselves as,

committed to nurturing intellect so that we could become scholars, thinkers, and cultural workers - black folks who used our 'minds'. We learned early that our devotion to learning, to a life of the mind, was a counter-hegemonic act, a fundamental way to resist every strategy of white racist colonization. (hooks, 1994, p. 2)

hooks described her teachers as embodying a "revolutionary pedagogy of resistance that was profoundly anticolonial" (p. 2). Teaching practice was intended to contribute to "uplifting the race." hooks describes how her teacher's approaches have been shaped by both her Black Journal of Contemporary Issues in Education, 2021, 16(2), pp. 3-20. 
teachers (working in working class Black communities) and Paulo Freire's "Pedagogy of the Oppressed" (Freire, 1970, in hooks, 1994, p. 51) in supporting literacy development among the working poor. The merging of Black feminism with critical pedagogy garnered the engaged pedagogy that hooks went on to develop in her writings about her teaching approaches (hooks, 1994, 2010).

\section{Converging Literacy Acquisition With the Feminist Pedagogic Agenda to Empower Students}

Engaging students in developing literacy skills is essential in the process of empowering learners. In whatever subject area — whether history and politics or literature - the methodology to achieve this end departs from the following perceptions of the teacher:

1. She consciously validates the experiences and knowledge basis students bring to the classroom. She gives space within the classroom for students to verbally articulate their everyday experiences as Black women (or whatever their location may be).

2. She creates an intellectual partnership that "lessens the power imbalance and class differences between instructor and students" (hooks, 1989, p. 52). As students discuss their insights, the teacher makes the process conscious and the content significant by "assisting them by adding the factual, analytical, and contextual information that illuminates and expands their insights" (Omolade, 1987, p. 35). The classroom environment allows for the development of communication and oral literacy skills.

3. She uses literacy to connect the "primary discourse"of students or their social network and "identity kit" (Gee, 1992, p. 21) with the dominant discourse of the ruling elite (Giroux, 1991). When histories and ideas are connected across racial, gender, and class boundaries, knowledge that is acquired through such a multifocal point of view gives students from oppressed and exploited groups an opportunity to come to voice (Butler, 1991b) .

4. She focuses on the teacher-student relationship and the issue of power to question how she can use power in a way that is not coercive and damaging. She is critical of "a liberal feminist stance because it has (unknowingly) been used to deny the students an honest appraisal of their learning and skills" (Omolade, 1987, p. 36), for fear that to do so would be to exercise domination. She recognizes that "we must acknowledge that our role as teacher is a position of power over others. We can use that power in ways of teaching that diminish or in ways that enrich and it is this choice that should distinguish feminist pedagogy from ways of teaching that reinforce domination" (hooks, 1989, p. 52).

5. Scholarly written skills and critical thinking are emphasized for the purpose of helping Black women analyze, theorize, and contextualize about their lives with the knowledge that they are making history (Omolade, 1987).

6. In the feminist classroom, students and teachers alike engage in a sense of struggle. Teaching and learning is at times interchangeable, as the participants unlearn and replace old ideas and limited understandings with better information. As they work to shift paradigms and change consciousness, education becomes the practice for liberatory pedagogy (hooks, 1989). 


\section{The Struggle for Black Feminist Pedagogy as a Viable Alternative Pedagogy}

Bell-Scott and Sheftall (1989) outline several issues that are major deterrents in the formulation of a viable Black pedagogy. I consider two of these imposing limitations as most crucial to weakening a Black feminist pedagogy that can be disseminated and used widely (by people who are not biologically Black or female). "Not enough courses or scholarship with a pro-woman and pro-Black analytical framework ... [and] too few Black women scholars with the courage and support to reject the biases of the Western tradition" (p. 2). Hull and Smith (1982) give an insider's perspective into the view of the gate keepers (White male patriarchy) in academia: "The act of a Black person teaching and sharing knowledge (is) viewed as naturally threatening to the power structure. The knowledge conveyed (has) a political and material transforming function, that is, it empower(s) people to gain freedom" (p. xix).

Ruth Farmer's (1993) narrative in Spirit, Space and Survival is a living testimony of Black women's attempts to eradicate the canon in academia and the resulting acts to silence them. Farmer's attempts to reorganize Barnard's Center for Research on Women (BCROW) as Associate Director was called to a complete halt when she was fired for attempting to create a space for the significant contributions of women of color within women's studies and multicultural studies. bell hooks (1991) cites Patricia Williams's collection of essays The Alchemy of Race and Rights in order to recount the dilemma of the Black female intellectual. hooks (1991) sums up the constraining elements of Williams experiences (in item 2 above):

[When] Black female students and professors engage in critical thinking, intellectual work that threatens the status quo, it makes it difficult for us to receive necessary support and affirmation. Naming that racism and sexism combined ensures that we will be seen by colleagues with narrow perspectives as intruders. Williams makes it clear that "outsider status is a kind of unresolved wound." Some of us choose then to deny our intellectual ability so as not to confront this reality. Others may choose to be academics but eschew the category "intellectual." (p. 152)

In the transformed curriculum and pedagogy, multiple voices will be heard and legitimized. Butler's (1991a) attempts to bridge Black studies (ethnic studies) and women's studies in "An Overdue Partnership" ( $\mathrm{p}$. xvii) perhaps held promises to produce the coalition that is necessary to achieve the transformative curriculum and pedagogic goals the two groups have espoused as autonomous entities. It was hoped that Black feminists will play a significant role in forwarding this movement in the area of curriculum content and teaching practices. It was envisioned that a viable Black feminist pedagogy will be nurtured and disseminated within this demand for a pluralistic, multidimensional, multifocal, interdisciplinary scholarship and pedagogy (Butler, 1991b, p. 84).

Black feminist theorists Michele Wallace (1982) and "A Black Feminist Statement: The Combahee River Collective" (1982) captured the challenges Black women underwent during the latter part of the 20th century. Both viewpoints speak to thoughts and experiences that reverberated throughout Black women's struggle for inclusion during the 1980s-1990s:

We exist as women who are Black who are feminist, each stranded for the moment, 
working independently because there is not yet an environment in this society remotely congenial to our struggle - because, being on the bottom we would have to do what no one else has done: we would have to fight the world....We might use our position at the bottom, however, to make a clear leap into revolutionary action. If Black women were free, it would mean that everyone else would have to be free since our freedom would necessitate the destruction of all the systems of oppression. (Combahee River Collective, 1982, p. 18)

\section{The Struggle for Inclusion Continues in Contemporary Black Feminist Researchers' Critique of "Epistemic" Exclusion}

The present-day critique among contemporary Black feminists (Evans-Winters \& Piest, 2014) regarding the processes that undermine the history of Black women's contribution to educational theory, such as critical pedagogy, is important to point out. Their argument accounts for what Buchanan (2020) describes as "epistemic exclusion." Njoki Nathani Wane (2009) discusses the perspectives of 16 Black women who participated in her study on how Black women conceptualize and theorize feminism. Wane identifies the purpose of her inquiry as focused on the unique voices of each participant and how they provide an avenue for exploring "feminist theorizing among women of African ancestry in Canada" (p. 65). While Wane makes known the heterogeneity among women's views, she focuses on at least 5 concepts the women use to not just survive but thrive in the academy. She identifies these as: "their stories of agency, resiliency, survival and skills and strategies..." (p. 65).

An important insight that Wane provides are how the women negotiate with what other Black researchers have identified as epistemic marginalization. Albeit the participants were graduate students whereas previous studies discussing 'epistemic marginalization' are focused on faculty members. However, Wane does help to discern how epistemic marginality begins much earlier in the Black women's academic trajectory. At the same time and most importantly, Wane makes known the resistance women use to forge their continued presence in the academy. It's the spirit of the women and their spiritual anchoring that renews their commitment and recommitment to living and being whole rather than fragmented as they pursue their studies. These insights provide hope for the future of Black women academics. At the same time Wane makes known the threat to women's survival comes from the oppressive structural continuities embedded in institutional practices that bare print on the psyche such as racism, sexism, an exclusionary curriculum. She explains: "The participants in my research indicated that although Black women contribute to different theories, various policies or structures in institutions still silence them, including feminist voices in these institutions" (Wane, 2009, p.71).

Writing in the early 2000s, I reported on the challenges black women experienced from an exclusionary feminist curriculum and the critique that they provided much of which is aligned with a now well-known body of research on the limitations on the second wave in feminism (Mogadime, 2002, 2003). The importance of the study was with reference to Black women students' own voices expressed about their sense of alienation and resistance to these limitations. Additionally, I discussed the nuances in the academic socialization process that impacted on black women's prospects as new and burgeoning scholars (Mogadime, 2002). I argue that they face a different set of constraints due to their race and gender. Wane's research points to how Journal of Contemporary Issues in Education, 2021, 16(2), pp. 3-20. 
black women students' presence contributes to knowledge production while pushing the boundaries also takes a personal toll on women's psyche and how they use spirituality to stay anchored in their studies $(2009$, p. 72).

What distinguishes Wane's research $(2009,2011)$ is that she has written about the role of spirituality as a conduit for decolonizing pedagogical approaches. In "Reclaiming our spirituality: A pedagogical tool for feminism and activism", Wane discusses her interviews with 5 Black women and draws from her own autobiographical reflections to surmise that spirituality is central for both their "activism and transformative feminism" (Wane, 2011, p. 160). In the section on "Spirituality and Rootedness" Wane expands, as follows:

All five women interviewed had a strong sense of being Black and being rooted in African spiritual practices....Each of the women's spirituality is rooted in a particular geographical space, a place they call home or sacred, a place cherished by family members, or place that the women remembered or talked about with fond memories. (pp. 161-162)

Participants featured in Wane's study spoke about how spirituality as intergenerational knowledge basis augmented by their connections to the community and rendered important components for their action oriented academic perspectives. Their mothers, aunties and grandmothers were discussed as part of the intergenerational connections, and relational impetus for community action. Wane surmises that as a result of their relational intergenerational knowledge and self-reliance, the women were able to challenge racism and discrimination: "Their measure of success was on how self-reliant they were; how well they connected with the various communities; how well they were grounded in terms of their spiritual practices; and how successful they were in challenging the status quo" (Wane, 2009, p. 69). Agyepong's (2011) review of the literature augments the assertions regarding the important role of spirituality, that Wane advances.

The challenges that Black women undergo in contemporary times can only be fully appreciated with the historical knowledge of Black women's struggle for inclusion in academia that occurred during the 1980s and 1990s. For example, current challenges still endure in terms of the White male stronghold in the fields where critical pedagogy is espoused in the field of education. Black researchers continue to point to the precarious problem of Black women on the margins. The statistics on Black women in higher education in the United States of America bear witness to why such challenges are long-standing. For example, Buchanan (2020) mentions that of the nearly 800,000 full-time faculty at degree granting institutions, Black women are conspicuous in their absence, representing only $0.8 \%$ of assistant, $0.5 \%$ of associate, and less than $0.3 \%$ of full professors.

When it comes to Canada, the statistics regarding the employment of Black women faculty is not known. Instead, the Canadian Association of University Teachers' (CAUT, 2020) Almanac of Post-Secondary Education in Canada refers to "visible minority groups" as follows:

Underrepresentation of visible minority groups is more generalized among college instructors, with significantly more Aboriginal representation among college instructors 
than among the professoriate. $14.4 \%$ of college instructors are visible minorities and $3.0 \%$ identify as Aboriginal, which are both significantly less than their share of the adult workforce $(21.2 \%$ and $3.8 \%$ respectively).

(Section 3.18, para. 3)

Black women's marginality is evident in the fact that Blacks and Black women are not even disaggregated in relation to "visible minority groups" that CAUT discusses. Contemporary researchers in both the USA and Canada, such as Samuel and Wane (2005) as well as Henry $(2015,2017)$ substantiate this viewpoint extensively and have made known the fact that Black feminists require fortitude and resilience in order to continue to speak out against institutional racism and omission in institutions where they are often not supported.

\section{References}

Agyepong, R. (2011) Spirituality and the empowerment of Black women in the academy. Canadian Woman Studies, 29(1,2) (Fall 2011), 176-181.

Asante, M. K. (1993). Malcolm X as cultural hero \& other Afrocentric essays. Africa World Press.

Bambara, T. C. (1970). On the issue of roles. In T. C. Bambara (Ed.), The Black woman: An anthology (pp. 101-110). Washington Square Press.

Banks, J. (1991). A curriculum for empowerment, action, and change. In C. E. Sleeter (Ed.), Empowerment through multicultural education (pp. 125-141). State University of New York Press.

Bell-Scott, P., \& Guy-Sheftall, B. (1989). Black women' studies: On the threshold of phase two. Sage: A Scholarly Journal on Black Women, 6(1), 1-2.

Briskin, L. (1990). Feminist pedagogy: Teaching and learning liberation (CRIAW Feminist Perspectives no.19). CRIAW.

Bristow, P. (1994). "Whatever you raise in the ground you can sell it in Chatham": Black women in Buxton and Chatham, 1850-65. In P. Bristow (Ed.), We're rooted here and they can't pull us up: Essays in African Canadian women's history (pp. 69-142). University of Toronto Press.

Buchanan, N. T. (2020). Researching while Black (and female). Women \& Therapy, 43(1-2), 91-111. https://doi.org/10.1080/02703149.2019.1684681

Butler, J. E. (1991a). Introduction. In J. E. Butler \& J. C. Walter (Eds.), Transforming the curriculum: Ethnic studies and women's studies (pp. xvii-xx). State University of New York Press.

Butler, J. E. (1991b). Transforming the curriculum: Teaching about women of color. In J. E. Butler \& J. C. Walter (Eds.), Transforming the curriculum: Ethnic studies and women's studies (pp. 67-97). State University of New York Press.

Canadian Association of University Teachers. (2020). Almanac of post-secondary education: 3. Academic staff. https://www.caut.ca/resources/almanac/3-academic-staff

Carby, H. (1992). The multicultural wars. In G. Dent (Ed.), Black popular culture (pp. 187-199). Bay Press.

Carty, L. (Ed.). (1993). And still we rise: Feminist political mobilizing in contemporary Canada. Women's Press. 
Carty, L. (1991). Black women in Academia: A statement from the periphery. In Bannerji, H., Carty, L., Dehili, K., Heald, S. \& McKenna, K. (Ed.), Unsettling relations: The university as a site of feminist struggle (pp. 13-44). Women's Press.

Carty, L. (1987). Women's studies in Canada: A discourse and praxis of exclusion. Resources for Feminist Research, 20(3-4), 12-18.

Chilisa, B., \& Ntseane, G. (2010). Resisting dominant discourses: Implications of Indigenous, African feminist theory and methods for gender and education research. Gender \& Education, 22(6), 617-632. doi:10.1080/09540253.2010

Coleman-Burns, P. (1993). The revolution within: Transforming ourselves. In J. James \& R. Farmer (Eds.), Spirit, space and survival: African American women in (White) academe (pp. 139-157). Routledge.

Collins, P. H. (1989). The social construction of Black feminist thought. Signs, 14(4), 745-773. https://doi.org/10.1086/494543

Collins, P. H. (1991). Black feminist thought: Knowledge consciousness and the politics of empowerment. Routledge.

Combahee River Collective. (1982). A Black feminist statement: The Combahee River Collective. In Hull, G. T., Bell-Scott, P., \& Smith, B. (Eds.), All the women are White, all the Blacks are men, but some of us are brave: Black women's studies (pp. 13-22). Feminist Press.

Culley, M. (1985). Anger and authority in the introductory women's studies classroom. In Culley, M., and Portugues (Eds.), Gendered subjects: The dynamics offeminist teaching. 209-218.

Das Gupta, T. (1994). Towards an anti-racist, feminist teaching method. In P. Bourne, P. Mater, N. Amin, M. Gonick, \& L. Gribowski (Eds.), Feminism and education: A Canadian perspective (Vol. 2, pp. 17-42). Centre for Women's Studies in Education, OISE.

Davis, A. (1993) Forward. In J. James \& R. Farmer (Eds.), Spirit, space and survival: African American women in (White) academe (pp. xi-xii). Routledge.

Evans-Winters, V. E., \& Piest, J. (2014). The skin we speak: Locating Black women in critical pedagogy. In P. W. Orelus \& R. Brock (Eds.), Interrogating critical pedagogy: The voices of educators of color in the movement (pp. 30-45). Taylor \& Francis.

Farmer, R. (1993). Place but not importance: The race for inclusion in academe. J. James \& R. Farmer (Eds.), Spirit, space and survival: African American women in (White) academe (pp. 196-217). Routledge.

Freire, P. (1970). Pedagogy of the oppressed. New York: Seabury Press.

Gee, J. P. (1992). What is literacy? In P. Shannon (Ed.), Becoming political readings and writings in the politics of literacy education (pp. 21-41). Heinemann: Porsmouth, $\mathrm{NH}$

Giroux, H. (1991). Postmodernism as border pedagogy: Redefining the boundaries of race and ethnicity. In H. Giroux (Ed.), Post modernism, feminism and cultural politics: Redrawing educational boundaries (pp. 235-245). State University of New York Press.

Giroux, H. A. (1992). Border crossings : cultural workers and the politics of education . New York : Routledge.

Guy-Sheftall, B. (1993). A Black feminist perspective on transforming the academy: The case of Spelman College. In S. M. James \& A. P. A. Busia (Eds.), Theorizing Black feminisms: The visionary pragmatism of Black women (pp. 77-89). Routledge.

Henry, A. (1992). Taking back control: Toward an Afrocentric womanist standpoint on the 
education of Black children [Unpublished doctoral dissertation]. University of Toronto.

Henry, A. (2015) 'We especially welcome applications from members of visible minority groups': reflections on race, gender and life at three universities, Race Ethnicity and Education, 18:5, 589-610, DOI: 10.1080/13613324.2015.1023787

Henry, A. (2017). Dear white people, wake up, Canada is racist. The Conversation. Available at https://theconversation.com/dear-white-people-wake-up-canada-is-racist-83124

hooks, b. (1981). Ain't I a woman: Black women and feminism. South End Press.

hooks, b. (1984). Feminist theory: From margin to center. South End Press.

hooks, b. (1989). Talking back: Thinking feminist, thinking Black. South End Press.

hooks, b. (1991). Black women intellectuals. In C. West \& b. hooks (Eds.), Breaking bread: Insurgent Black intellectual life (pp. 147-164). Between the Lines.

hooks, b. (1994). Teaching to transgress: Education as a practice of freedom. Routledge hooks, b. (2010). Teaching critical thinking: Practical wisdom. Routledge.

Hill, P. C. (1994). "Breaking Bread: Insurgent Black Intellectual Life" by bell hooks and Cornel West (Book Review) [Review of "Breaking Bread: Insurgent Black Intellectual Life" by bell hooks and Cornel West (Book Review)]. Signs, 20(1), 176-. University of Chicago Press.

Hull, G. T., Bell-Scott, P., \& Smith, B. (Eds.). (1982). All the women are White, all the Blacks are men, but some of us are brave: Black women's studies. Feminist Press.

Hull, G. T., \& Smith, B. (1982). Introduction: The politics of Black women's studies. In G. T. Hull, P. Bell-Scott, \& B. Smith (Eds.), All the women are White, all the Blacks are men, but some of us are brave: Black women's studies (pp. xvi-xxxiv). Feminist Press.

James, J. (1993). Teaching theory, talking community. In J. James \& R. Farmer (Eds.), Spirit, space and survival: African American women in (White) academe (pp. 118-135). Routledge.

Johnson, E. (1993a). Teaching theory, talking community. In J. James \& R. Farmer (Eds.), Spirit, space and survival: African American women in (White) academe (pp. 118-138). Routledge.

Johnson, E. (1993b). Working-class women as students and teachers. In M. M. Tokarczyk \& E. A. Fray (Eds.), Working class women in the academy: Laborers in the knowledge factory (pp. 197-207). University of Massachusetts Press.

Joseph, P. E. (2003). Dashikis and democracy: Black studies, student activism, and the Black Power Movement. The Journal of African American History, 88(2), 182-203. https://doi.org/10.2307/3559065

Mogadime, D. (2003). Contradictions in feminist pedagogy: Black women students' perspectives. Resources for Feminist Research/Documentation Sur La Recherche Feminste (RFR/DRF), 30(1/2), 7-32.

Mogadime, D. (2002). Black women in graduate studies: transforming the socialization experience. In N. Nathani Wane, K. Dliovsky, \& E. Lawson (Eds.), Back to the drawing board: African Canadian feminism(s) (pp. 129-157). Toronto: Sumach Press.

Omolade, B. (1987). A Black feminist pedagogy. Women's Studies Quarterly, 15(3-4), 15-31. https://tinyurl.com/yykyrf88

Russell, M. (1982). Black-eyed blues connections: Teaching Black women. In G. T. Hull, P. Bell-Scott, \& B. Smith (Eds.), All the women are White, all the Blacks are men, but some of us yare brave: Black women's studies (pp. 196-207). Feminist Press. 
Samuel, E., \& Wane, N. N. (2005). "Unsettling relations": Racism and sexism experienced by faculty of color in a predominantly white Canadian University. The Journal of Negro Education, 74(1), 76-87.

Smith, B. (1983). Home girls: A Black feminist anthology. Kitchen Table: Women of Color Press.

Wallace, M. (1982). A Black feminist's search for sisterhood. In G. T. Hull, P. Bell-Scott, \& B. Smith (Eds.), All the women are White, all the Blacks are men, but some of us yare brave: Black women's studies (pp. 5-12). Feminist Press.

Wane, N. N. (2009) Black Canadian feminist thought: perspectives on equity and diversity in the academy, Race Ethnicity and Education, 12(1), 65-77, https://doi.10.1080/13613320802650964

Wane, N. N. (2011) Reclaiming our spirituality: A pedagogical tool for feminism and activism. Canadian Woman Studies, 29(1/2), 159-170.

Weiler, K. (1988). Women teaching for change: Gender, class and power. Bergin \& Garvey.

West, C. (1994). Race matters. Vintage Books. 